\title{
PENGARUH PROFITABILITAS DAN LIKUIDITAS TERHADAP NILAI PERUSAHAAN DENGAN STRUKTUR MODAL SEBAGAI VARIABEL INTERVENING (STUDI PADA PERUSAHAAN MANUFAKTUR YANG TERDAFTAR DI BURSA EFEK INDONESIA SEKTOR INDUSTRI BARANG KONSUMSI PERIODE 2015-2019)
}

\author{
Falen Sadewo ${ }^{1}$, Budi Santoso ${ }^{2}$, I Nyoman Nugraha AP 3 \\ ${ }^{1}$ Master of Management Program, Mataram University, Indonesia. \\ E-mail : falensadewo21@gmail.com \\ 2,3Faculty of Economics and Business, Mataram University, Indonesia
}

\begin{abstract}
ARTICLE INFO
Keywords:

Capital Structure, Firm Value, Liquidity, Profitability.

Kata Kunci :

Likuiditas, Nilai Perusahaan, Profitabilitas, Struktur Modal.

How to cite:

Sadewo, Falen., Santoso, Budi., Putra, I Nyoman Nugraha., (2022). Pengaruh Profitabilitas Dan Likuiditas Terhadap Nilai Perusahaan Dengan Struktur Modal Sebagai Variabel Intervening (Studi Pada Perusahaan Manufaktur Yang Terdaftar Di Bursa Efek Indonesia Sektor Industri Barang Konsumsi Periode 2015-2019). JMM UNRAM, $11(1), 39-55$
\end{abstract}

DOI:

10.29303/jmm.v11i1.704

Dikumpulkan : 18 Februari 2022

Direvisi : 21 Februari 2022

Dipublikasi : 22 Februari 2022

\section{ABSTRACT}

This study aims to analyze the effect of profitability and liquidity on firm value through capital structure as an intervening variable in manufacturing companies in the consumer goods industry listed on the Indonesia Stock Exchange. This type of research is quantitative research. The sampling method used was purposive sampling method. Samples obtained as many as 28 companies from 2015 to 2019. To answer the hypothesis, this study uses multiple linear regression panel data which is analyzed using Eviews version 9 and path analysis. The result of this study shows profitability and capital structure have significant effect on firm value, while liquidty has no effect on firm value. Profitability has no effect on capital structure and liquidity affects capital structure. Furthermore, capital structure has not been able to mediate the effect of profitability on firm value. Capital structure is able to mediate the effect of liquidity on firm value. In allocating owned funds, it is necessary to be more careful in analyzing the performance of a company such as by looking at profitability, liquidity, capital structure to increase the expected value of the company.

Penelitian ini bertujuan untuk menganalisis pengaruh profitabilitas dan likuiditas terhadap nilai perusahaan melalui struktur modal sebagai variabel intervening di Perusahaan Manufaktur sektor Industri Barang Konsumsi yang terdaftar di Bursa Efek Indonesia. Jenis penelitian ini adalah penelitian kuantitatif. Metode pengambilan sampel yang digunakan dengan metode purposive sampling. Sampel yang diperoleh sebanyak 28 perusahaan dari tahun 2015-2019. Untuk menjawab hipotesis, 


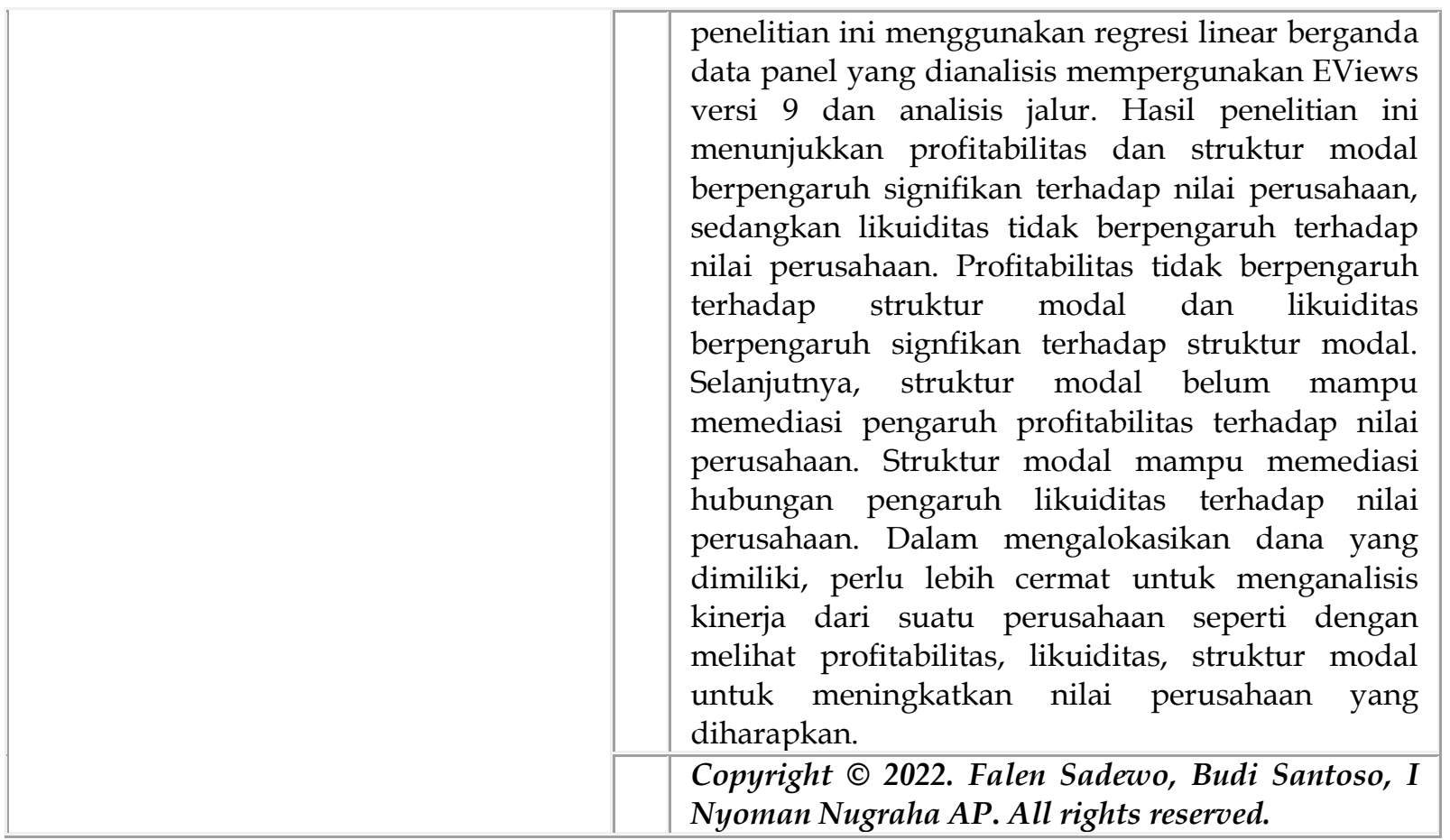

\section{LATAR BELAKANG}

Perusahaan Manufaktur yang terdaftar di Bursa Efek Indonesia menjadi salah satu perusahaan yang cukup diminati dalam perdagangan pasar saham. Berdasarkan informasi dari kontan.co.id (2020) sektor manufaktur yang terdaftar di Bursa Efek Indonesia berada pada indeks sub sektor barang konsumsi hanya terkoreksi 5,5\% sejak awal tahun karena adanya pandemi COVID - 19. Bandingkan dengan indeks sub sektor properti yang ambles hingga 34,8\% dan indeks sub sector aneka industri yang turun hingga 29,55\% sejak awal tahun atau secara year-to-date (ytd). Data tersebut dapat dikatakan bahwa sub-sektor barang konsumsi memiliki penurunan harga saham yang paling kecil daripada sektor lainnya ditambah dengan adanya guyuran stimulus dari pemerintah, seperti bantuan langsung tunai (BLT) berupa subsidi gaji barang konsumsi bakal semakin prospektif (kontan.co.id, 2020). Hal ini tentunya akan berdampak terhadap nilai perusahaan.

Nilai perusahaan merupakan suatu hal yang penting bagi perusahaan, terutama bagi perusahaan yang telah memiliki citra baik di masyarakat luas. Menjaga nilai perusahaan akan memiliki dampak bagi keuangan perusahaan sehinga membuat investor tertarik untuk membeli saham perusahaan tersebut. Salah satu tujuan jangka panjang bagi perusahaan adalah meningkatkan kesejahteraan pemegang saham melalui peningkatan nilai perusahaan dengan memaksimalkan harga saham perusahaan (Brigham \& Houston, 2014). Nilai perusahaan memberikan gambaran kepada para pemegang saham mengenai baik buruknya suatu perusahaan dikelola. Bila manajemen mengelola perusahaan dengan efektif dan efisien maka nilai perusahaan dapat meningkat. Harga saham dapat mencerminkan nilai perusahaan, karena harga saham dan nilai perusahaan memuat penilaian kolektif investor tentang seberapa baik kinerja sebuah perusahaan, baik kinerjanya saat ini dan prospek masa depannya (Brealey, et al 2011).

Tolok ukur yang sering digunakan untuk mengukur nilai perusahaan adalah price book value (PBV), yang dapat diartikan sebagai hasil dari perbandingan antara harga saham dengan nilai buku. Berdasarkan rasio PBV, dapat dilihat bahwa nilai perusahaan yang baik 
ketika nilai PBV di atas satu (overvalued) yaitu nilai pasar lebih besar daripada nilai buku perusahaan. Semakin tinggi price book value (PBV) berarti perusahaan semakin berhasil menciptakan nilai atau kemakmuran bagi pemegang saham. Sebaliknya, apabila PBV di bawah satu (undervalued) mencerminkan nilai perusahaan tidak baik (Nurminda dkk., 2017).

Profitabilitas adalah kemampuan perusahaan untuk memperoleh laba dalam hubungannya dengan penjualan, total asset maupun modal sendiri. Profitabilitas merupakan kemampuan perusahaan dalam menghasilkan laba. Profitabilitas yang tinggi mencerminkan kemampuan perusahaan dalam menghasilkan keuntungan yang tinggi bagi pemegang saham. Tingkat profitabilitas yang tinggi akan diminati sahamnya oleh investor, sehingga permintaan saham meningkat dan harga saham akan naik (Mulyani, Amboningtyas, \& Fathoni, 2017). Profitabilitas akan diukur menggunakan return on asset (ROA). Penelitian yang dilakukan sebelumnya menyatakan profitabilitas berpengaruh terhadap nilai perusahaan dilakukan oleh Sari \& Sedana, (2020); Putra \& Sedana, (2019); Mulyani et al., (2017); Nurminda et al., (2017); Sabrin, Sarita, Takdir, \& Sujono, (2016) dan Wulandari, (2013). Dalam beberapa penelitian lain menunjukkan hasil berbeda yang dilakukan oleh Savitri, Kurniasari, \& Mbiliyora, (2021); Septriana \& Mahaeswari, (2019) dan Manoppo \& Arie, (2016) yang menyebutkan profitabilitas tidak memiliki pengaruh terhadap nilai perusahaan.

Faktor lain yang mempengaruhi nilai perusahaan adalah likuiditas. Likuiditas merupakan suatu kemampuan untuk memenuhi kewajiban jangka pendek. Likuiditas sangat penting bagi suatu perusahaan dikarenakan berkaitan dengan mengubah aktiva menjadi kas (Brigham \& Houston, 2014). Tingginya likuiditas menunjukkan perusahaan dapat menurunkan dampak yang diakibatkan oleh kewajiban keuangan jangka pendek, dan sebaliknya. Tinggi rendahnya rasio ini akan mempengaruhi persepsi investor terhadap perusahaan jika memiliki nilai likuiditas tinggi yang menunjukkan kinerja perusahaan baik, sehingga akan meningkatkan harga saham yang mencerminkan nilai perusahaan. Likuiditas dalam penelitian ini diukur menggunakan current ratio. Penelitian yang dilakukan oleh Sari \& Sedana, (2020); Putra \& Sedana, (2019); Septriana \& Mahaeswari, (2019); Mulyani et al., (2017); menyatakan bahwa likuiditas memiliki pengaruh terhadap nilai perusahaan. Beberapa penelitian lain yang telah dilakukan menyatakan likuiditas tidak memiliki pengaruh terhadap nilai perusahaan yaitu oleh Aslindar \& Lestari, (2020); Rahmatullah, (2019) dan Wulandari, (2013).

Pemilik perusahaan akan selalu menunnjukkan kepada calon investor bahwa perusahaan mereka tepat sebagai alternatif investasi melalui pihak manajemen. Pihak manajemen diharapkan mampu memberikan sinyal positif terhadap para calon investor. Manajer menyampaikan sinyal kepada investor melalui pengaturan struktur modal (Brigham \& Houston, 2014). Kesalahan dalam menentukan struktur modal akan memberikan dampak bagi perusahaan terutama pada perusahaan yang cukup besar dalam menggunakan utang, maka akan semakin besar beban tetap yang harus ditanggung perusahaan juga. Struktur modal yang optimal suatu perusahaan adalah kombinasi dari utang dan ekuitas yang dapat mempengaruhi harga saham perusahaan. Pada saat tertentu, manajemen perusahaan menetapkan struktur modal yang di targetkan, yang mungkin merupakan struktur yang optimal, meskipun target tersebut dapat berubah dari waktu ke waktu. Beberapa perusahaan mengalami kemunduran karena struktur modal tidak mengalami penyesuaian antara cara pemenuhan dana dengan jangka waktu kebutuhannya. Perusahaan-perusahaan tersebut harus menanggung modal yang besar dikarenakan pendanaan dari unsur hutang lebih besar dari pada modal sendiri, sehingga penggunaan dana yang digunakan untuk aktivitas operasional perusahaan lebih banyak 
menggunakan unsur hutang. Untuk mengantisipasi hal tersebut, manajer keuangan perusahaan harus berhati-hati dalam menetapkan struktur modal yang diharapkan perusahaan dapat meningkatkan nilai perusahaan lebih unggul dalam mengahadapi persaingan bisnis, menghitung profitabilitas dan memenuhi kebutuhan jangka pendeknya (likuiditas).

Penelitian ini menggunakan struktur modal sebagai variabel intervening untuk mengetahui hubungannya dengan profitabilitas dan likuiditas terhadap nilai perusahaan. Struktur modal dalam penelitian ini diukur menggunakan debt equity ratio (DER). Hasil penelitian dari Sari \& Sedana, (2020); Putra \& Sedana, (2019); dan Mulyani et al., (2017) yang mengungkapkan bahwa nilai perusahaan dipengaruhi oleh profitabilitas dan likuiditas ketika dimediasi dengan struktur modal. Sedangkan Rahmatullah, (2019) dan Wulandari, (2013) menjelaskan bahwa pengaruh antara profitabilitas dan likuiditas terhadap nilai perusahaan tidak dapat dimediasi oleh struktur modal.

Berdasarkan pemaparan di atas, maka tujuan penelitian adalah:

1. Untuk menganalisis pengaruh profitabilitas terhadap nilai perusahaan.

2. Untuk menganalisis pengaruh likuiditas terhadap nilai perusahaan.

3. Untuk menganalisis pengaruh profitabilitas terhadap struktur modal.

4. Untuk menganalisis pengaruh likuiditas terhadap struktur modal.

5. Untuk menganalisis pengaruh struktur modal terhadap nilai perusahaan.

6. Untuk menganalisis mediasi struktur modal pada pengaruh profitabilitas terhadap nilai perusahaan.

7. Untuk menganalisis mediasi struktur modal pada pengaruh likuditas terhadap nilai perusahaan.

\section{KAJIAN PUSTAKA}

\subsection{Signalling Theory}

Signalling theory atau teori sinyal adalah suatu tindakan yang diambil perusahaan untuk memberi petunjuk bagi investor tentang bagaimana manajemen memandang prospek perusahaan. Sinyal ini berupa informasi mengenai apa yang sudah dilakukan manajemen untuk merealisasikan keinginan pemilik (Besley \& Brigham, 2008). Informasi tersebut dapat tersampaikan melalui pengaturan struktur modal perusahaan. Pengaturan struktur modal perusahaan dapat dilakukan melalui penjualan saham baru atau memperoleh dana melalui hutang (Van Horne, Wachowicz, \& John, 2005). Sinyal merupakan suatu hal yang digunakan manajemen untuk memberikan informasi kepada investor dengan memperlihatkan apa yang diinginkan oleh pemegang saham telah terpenuhi.

Informasi yang diberikan oleh perusahaan merupakan hal yang sangat penting, karena pengaruhnya terhadap keputusan investasi. Informasi sangat dibutuhkan bagi investor dan pelaku bisnis karena informasi pada umumnya menyajikan keterangan, catatan baik untuk keadaan masa lalu, saat ini maupun masa yang akan datang bagi kelangsungan hidup perusahaan. Apabila informasi tersebut dipublikasikan dan para pelaku bisnis telah menerima informasi, para pelaku bisnis akan terlebih dahulu menganalisis informasi tersebut bahwa apakah informasi tersebut sebagai good news atau bad news.

\subsection{Trade - Off Theory}

Teori trade-off yang diperkenalkan oleh Modligiani dan Miller (MM) pada 1963 adalah teori yang menjelaskan bahwa struktur modal yang optimal ditemukan dengan 
menyeimbangkan manfaat dari pendanaan dengan hutang (perlakukan pajak perseroan yang menguntungkan) dengan suku bunga dan kebangkrutan yang lebih tinggi (Brigham \& Houston, 2014). Semakin besar hutang yang digunakan semakin tinggi nilai perusahaan. Model ini mengabaikan faktor biaya kebangkrutan dan biaya - biaya keagenan. Struktur modal yang optimal dapat ditemukan dengan menyeimbangkan antara keuntungan penggunaan hutang dengan biaya kebangkrutan dan biaya keagenan yang disebut model Trade-off theory.

Trade-off theory menjelaskan bahwa jika posisi struktur modal berada di bawah titik optimal maka setiap penambahan hutang akan meningkatkan nilai perusahaan. Sebaliknya, setiap jika posisi struktur modal berada di atas titik optimal maka setiap penambahan hutang akan menurunkan nilai perusahaan. Oleh karena itu, dengan asumsi titik target struktur modal optimal belum tercapai, maka berdasarkan trade - off theory memprediksi adanya hubungan yang positif terhadap nilai perusahaan.

\subsection{Pecking Order Theory}

Pecking order theory diperkenalkan oleh Donaldson tahun 1961. Tetapi pada tahun 1984, Myers memberi nama pecking order theory dilakukan oleh Myers pada tahun 1984 dalam jurnal yang berjudul the capital structure puzzle. Teori ini menjelaskan bahwa perusahaan lebih mengandalkan pembiayaan yang didapat hasil operasi perusahaan yang berupa laba ditahan atau yang biasa disebut dengan internal financing. Penerbitan obligasi dilakukan ketika perusahaan memerlukan pendanaan eksternal dengan resiko yang paling minim. Jika dana yang diperoleh tersebut masih tidak mencukupi perusahaan akan menerbitkan saham baru (Miglo, 2016). Dalam teoriPecking order dijelaskan urutan pendanaan suatuperusahaan di mana perusahaan pertama akanmenggunakan laba ditahan, kemudian hutang danterakhir adalah menerbitkan saham (Azmi, Isnurhadi, \& Hamdan, 2018)

\subsection{Nilai Perusahaan}

Nilai perusahaan merupakan indikator yang digunakan investor untuk melihat potensi yang ada dalam perusahaan tersebut. Potensi yang dimaksud adalah tingkat pengembalian dari investasi yang dilakukan oleh investor. Semakin tinggi nilai perusahaan, semakin tinggi pula tingkat pengembalian investasi. Nilai perusahaan memiliki arti sebagai ketika perusahaan dijual, maka investor akan membayar sesuai dengan nilai tersebut (Husnan, 2015). Rasio nilai perusahaan adalah sekumpulan rasio yang menghubungkan harga saham perusahaan dengan laba dan nilai buku per saham, rasio ini memberikan kepada manajemen petunjuk mengenai apa yang dipikirkan investor atas kinerja perusahaan di masa lalu serta prospek di masa mendatang (Mulyani et al., 2017).

Price to Book Value (PBV) adalah rasio yang menunjukkan apakah harga saham yang diperdagangkan overvalued (di atas) atau undervalued (di bawah) nilai buku saham tersebut (Mulyani et al., 2017). PBV juga menunjukkan seberapa jauh suatu perusahaan mampu menciptakan nilai perusahaan yang relative terhadap jumlah modal yang di investasikan. Untuk perusahaan-perusahaan yang berjalan dengan baik, umumnya rasio ini mencapai diatas satu, yang menunjukkan bahwa nilai pasar saham lebih besar dari nilai bukunya. Semakin besar nilai perusahaan maka semakin tinggi perusahaan dinilai oleh para pemodal relatif dibandingkan dengan dana yang telah ditanamkan di perusahaan. Tetapi dalam penelitian ini nilai perusahaan menggunakan rumus Price to Book Value (PBV). 


\subsection{Profitabilitas}

Profitabilitas merupakan tingkat keuntungan bersih yang mampu diperoleh perusahaan dalam menjalankan operasinya (Mahendra, Sri artini, \& Suarjaya, 2012).Analisis rasio profitabilitas merupakan analisis yang digunakan untuk mengukur kekuatan laba suatu perusahaan dalam mendayagunakan kekayaan yang ada untuk menghasilkan laba pada periode tertentu yang diukur melalui rasio-rasio profitabilitas.

Return on Assets (ROA) atau tingkat pengembalian Aset merupakan rasio profitabilitas untuk menilai persentase keuntungan (laba) yang diperoleh perusahaan terkait sumber daya atau total asset sehingga efisiensi suatu perusahaan dalam mengelola asetnya bisa terlihat dari persentase rasio ini. Rasio ini melihat sejauh mana investasi yang telah ditanamkan mampu memberikan pengembalian keuntungan sesuai dengan yang diharapkan. Dalam penelitian ini menggunakan ROA sebagai alat pengukur efisiensi penggunaan modal perusahaan.

\subsection{Likuiditas}

Menurut Rahmatullah, (2019) likuiditas adalah kesanggupan perusahaan untuk memenuhi utang yang memiliki jatuh tempo kurang dari satu tahun tepat pada waktunya. Perusahaan yang memiliki kemampuan untuk memenuhi kewajibannya dikatakan perusaaan likuid. Perusahaan yang memiliki tingkat likuiditas yang tinggi akan semakin dipercaya oleh investor karena memiliki dana yang besar dan digunakan untuk membiayai investasi. Secara umum terdapat beberapa jenis rasio likuiditas yang paling sering digunakan untuk mengukur kemampuan perusahaan.

Curret Ratio atau rasio lancar merupakan rasio untuk mengukur kemampuan perusahaan dalam membayar kewajiban jangka pendek atau hutang yang segera jatuh tempo pada saat ditagih secara keseluruhan. Dengan kata lain, seberapa banyak aktiva lancar yang tersedia untuk menutupi kewajiban jangka pendek yang segera jatuh tempo. Dalam penelitian ini menggunakan Current Ratio sebagai alat pengukur.

\subsection{Struktur Modal}

Menurut Savitri et al., (2021) struktur modal adalah komposisi pendanaan yang digunakan oleh perusahaan. Struktur modal berkaitan dengan penggunaan dana yang bersumber dari dalam maupun luar perusahaan. Struktur modal sangat penting karena berhubungan langsung dengan posisi keuangan perusahaan. Perusahaan dapat membuat kebijakan terkait struktur modal yang optimal sehingga dapat memaksimalkan kemakmuran pemegang saham. Struktur modal yang baik yaitu yang mencapai keseimbangan risiko dan return sehigga dapat memaksimalkan nilai perusahaan (Aslindar \& Lestari, 2020).

Struktur modal akan tampak pada Debt to Equity Ratio (DER) perusahaan. DER merupakan rasio perbandingan antara pembiayaan dan pendanaan melalui hutang dan modal sendiri. Keputusan pendanaan melalui modal dalam jumlah yang lebih besar dari pada melalui hutang dapat meningkatkan nilai perusahaan. Semakin tinggi rasio DER, maka semakin rendah pendanaan perusahaan yang disediakan oleh pemegang saham. Debt to Equity Ratio (DER) merupakan salah satu rasio leverage yang bertujuan untuk mengukur kemampuan dari modal sendiri yang dijadikan jaminan untuk keseluruhan hutang perusahaan. 


\subsection{Kerangka Konseptual Penelitian}

Gambar 1.

Kerangka Konseptual Penelitian

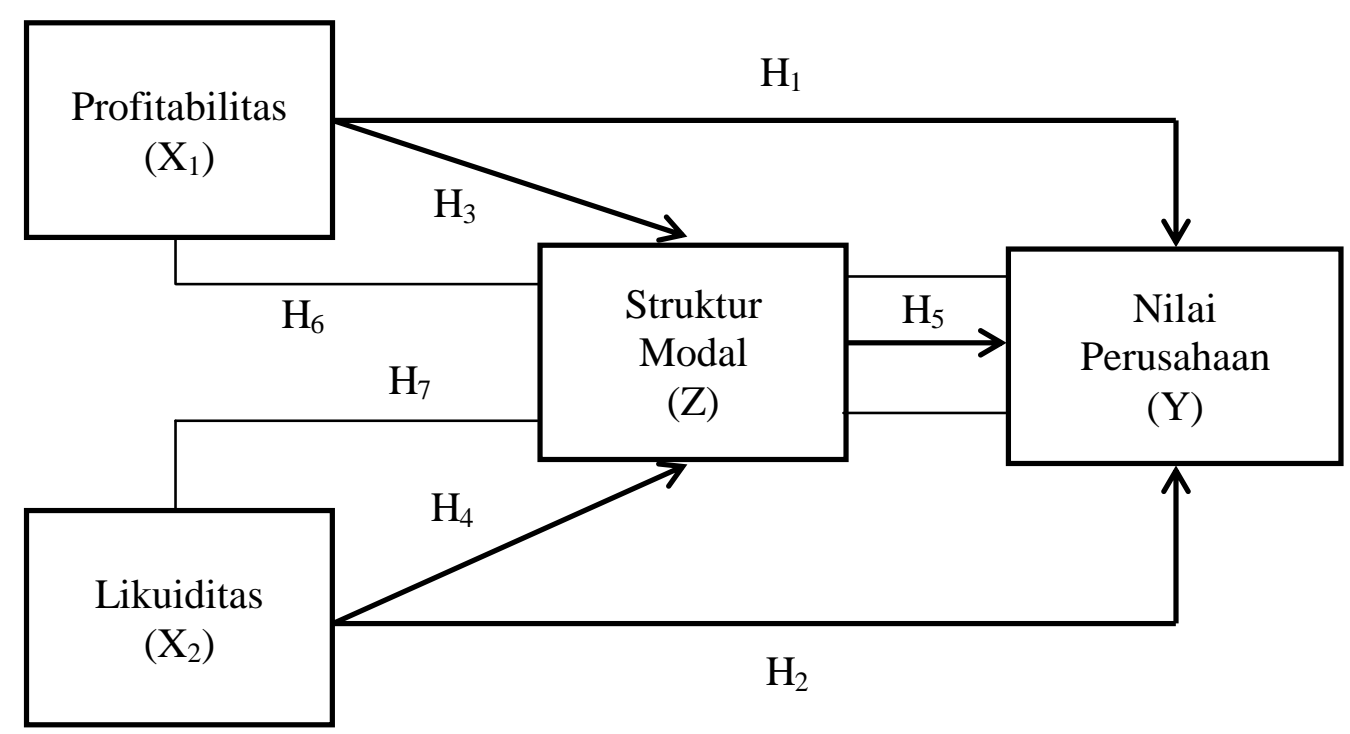

\section{METODE PENELITIAN}

\subsection{Jenis Penelitian}

Jenis penelitian ini adalah asosiatif kausal. Penelitian asosiatif kausal adalah penelitian yang dimaksudkan untuk mengungkapkan permasalahan yang bersifat hubungan sebab akibat antara dua variabel atau lebih (Sugiyono, 2013). Penelitian ini mencoba untuk mencari hubungan sebab akibat dari variabel-variabel yang diteliti. Penelitian ini bertujuan untuk mengetahui pengaruh profitabilitas dan likuiditas terhadap nilai perusahaan dengan struktur modal sebagai variabel intervening.

\subsection{Populasi dan Sampel}

Populasi merupakan keseluruhan kelompok orang, peristiwa, atau hal yang ingin peneliti investigasi (Sekaran, 2011). Populasi dalam penelitian ini seluruh perusahaan manufaktur sektor industri barang konsumsi yang telah go public dan terdaftar (listing) di Bursa Efek Indonesia pada tahun 2015-2019.

Sampel adalah bagian dari jumlah dan karakteristik yang dimiliki oleh populasi tersebut (Sugiyono, 2013). Metode pengambilan sampel yang akan digunakan dalam penelitian ini adalah metode purposive sampling dimana sampel yang terpilih berdasarkan kesesuaian karakteristik. Dalam purposive sampling, dilakukan penarikan sampel dengan tujuan yang sudah ada dan sudah terencana sebelumnya. 
Tabel 3.1

Kriteria Pengambilan Sampel

\begin{tabular}{clc}
\hline No. & \multicolumn{1}{c}{ Kriteria Sampel } & Jumlah \\
\hline 1. & $\begin{array}{l}\text { Perusahaan sektor industi barang konsumsi yang terdaftar di Bursa } \\
\text { Efek Indonesia periode tahun 2015-2019. }\end{array}$ & 53 \\
2. & $\begin{array}{l}\text { Perusahaan sektor industri barang konsumsi yang delisting periode } \\
\text { tahun 2015-2019. }\end{array}$ & (13) \\
3. $\begin{array}{l}\text { Perusahaan sektor industri barang konsumsi yang mengalami } \\
\text { kerugian atau laba negatif selama periode 2015-2019. }\end{array}$ & (12) \\
\hline $\begin{array}{l}\text { Total Sampel } \\
\text { Total Observasi ( } 5 \text { tahun ) }\end{array}$ & $\mathbf{1 4 0}$ \\
\hline
\end{tabular}

Sumber : Data diolah peneliti (2021)

\subsection{Definisi Operasional Variabel}

Adapun definisi operasional untuk variabel yang digunakan dalam penelitian ini sebagai berikut :

1. Nilai Perusahaan (Price Book Value)

Nilai perusahaan menggunakan rumus Price to Book Value (PBV) sebagai berikut:

(Brigham \& Houston, 2014)

$$
P B V=\frac{\text { Harga Pasar per Lembar Saham }}{\text { Nilai Buku per Lembar Saham }}
$$

2. Profitabilitas (ROA)

Perhitungan $R O A$ sebuah perusahaan dapat dihitung dengan menggunakan rumus :

(Brigham \& Houston, 2014)

3. Likuiditas

$$
R O A=\frac{\text { Laba Bersih }}{\text { Total Asset }}
$$

Likuiditas di ukur dengan Current Ratio (CR), yaitu rasio yang menunjukkan hubungan antara akitva lancar dengan kewajiban lancar. Proksi likuiditas sebagai berikut : (Kasmir, 2009)

4. Struktur Modal

$$
\text { Current Ratio }=\frac{\text { Aktiva Lancar (Current Assets })}{\text { Utang Lancar (Current Liabilities })}
$$

panjang terhadap modal sendiri. Struktur modal diukur dengan debt to equity ratio (DER). Rumus untuk mencari Debt to Equity Ratio sebagai berikut: (Aslindar \& Lestari, 2020)

$$
\text { Debt to Equity Ratio }=\frac{\text { Total Debt (Utang })}{\text { Equity }}
$$

\subsection{Prosedur Analisis Data}

Prosedur analisis data yang digunakan meliputi alanalisis statistik deskriptif, teknik analisis regresi data panel, analisis regresi, analisis asumsi dasar klasik, pengujian hipotesis, analis jalur (path analysis), dan uji sobel.

\subsubsection{Analisis Statistik Deskriptif}

Statistik deskriptif memberikan gambaran atau deskripsi suatu data yang dilihat dari nilai rata-rata (mean), standar deviasi, varian, maksimum, minimum, sum, range, kurtosis dan skewness (Ghozali, 2013). Analisis deskriptif digunakan dengan tujuan untuk memberikan deskripsi atau gambaran mengenai suatu data sampel atau populasi.

\subsubsection{Analisis Persamaan Regresi}

Dalam penelitian ini, teknik yang digunakan adalah teknik analisis regresi berganda, dengan path analysis. Koefisien analisis jalur didapatkan dari dua persamaan regresi dan satu koefisien korelasi. Dua persamaan regresi tersebut diperoleh dari tanda 
anak panah garis lurus satu arah. Persamaan regresi linier berganda dalam penelitian ini adalah :

Persamaan Struktural I :

$$
Z_{\text {DER }}=\alpha+\beta_{1} X_{1}+\beta_{2} X_{2}+\varepsilon
$$

Persamaan Struktural II :

$$
Y_{\mathrm{PBV}}=\alpha+\beta_{1} X_{1}+\beta_{2} X_{2}+\beta_{3} Z_{D E R}+\varepsilon
$$

Keterangan :

$\begin{array}{ll}\alpha & : \text { Konstanta } \\ \beta_{1}, \beta_{2}, \beta_{3}, \beta_{4} & : \text { Koefisien Regresi } \\ Z_{\mathrm{DER}} & : \text { Struktur Modal (DER) } \\ \mathrm{Y}_{\mathrm{PBV}} & : \text { Nilai Perusahaan (PBV) } \\ \mathrm{X}_{1} & : \text { Profitabilitas (ROA) } \\ \mathrm{X}_{2} & : \text { Likuiditas (CR) } \\ \varepsilon & : \text { Error }\end{array}$

\section{HASIL PENELITIAN DAN PEMBAHASAN}

\subsection{Statistik Deskriptif}

Statistik deskriptif digunakan untuk memberikan gambaran dan deskripsi data dari seluruh variabel-variabel dalam penelitian yang mencangkup nilai rata-rata (mean), nilai maksimum, nilai minimum, dan standar deviasi. Hasil dapat dilihat pada tabel berikut :

Tabel 4.1

Hasil Pengujian Statistik Deskriptif

\begin{tabular}{ccccccc}
\hline Variabel & Minimum & Maximum & Mean & $\begin{array}{c}\text { Std. } \\
\text { Deviation }\end{array}$ & Skewness & Kurtosis \\
\hline PBV & 01692 & 9,5896 & 2,721886 & 2,1401683 & 0,980734 & 3,077676 \\
DER & 0,0761 & 5,6368 & 0,814486 & 0,8076157 & 2,960844 & 15,50867 \\
ROA & 0,0005 & 0,9210 & 0,128018 & 0,1230289 & 2,780556 & 15,06565 \\
CR & 0,5842 & 8,6378 & 2,768863 & 1,7800867 & 1,174658 & 3,818066 \\
\hline
\end{tabular}

Sumber : Data Sekunder, diolah

Keterangan :

PBV = Nilai Perusahaan

DER = Struktur Modal

ROA = Profitabilitas

$\mathrm{CR} \quad=$ Likuiditas

\subsection{Uji Asumsi Klasik}

1. Uji Normalitas

Uji Normalitas digunakan untuk model regresi yang digunakan dalam penelitian memiliki data yang terdistribusi normal atau tidak. Jika data yang digunakan dalam penelitian tidak normal maka akan mempengaruhi hasil setiap test yang dilakukan. Untuk mengetahui data terdistribusi normal atau tidak dengan melihat nilai Prob. Jarque-Berra (JB), jika nilai Prob. JB lebih rendah dari $a=5 \%$ atau 0,05, maka data tidak terdistribusi normal. Berikut hasil uji normalitas pada persamaan struktur I dan struktur II. 
Tabel 4.2

Uji Normalitas

\begin{tabular}{|l|l|l|}
\hline & Model 1 & Model 2 \\
\hline Probability. JB & 0.477455 & 0.282051 \\
\hline
\end{tabular}

Sumber : Data Sekunder, diolah

Berdasarkan hasil uji normalita, pada persamaan struktur I hasil menunjukkan bahwa nilai probabilitas sebesar 0,477455 yang lebih dari $\alpha=5 \%$ atau 0,05 yang berarti memiliki data yang terdistribusi normal. Pada persamaan struktur II hasil menunjukkan bahwa nilai probabilitas sebesar 0,282051 yang lebih dari $\alpha=5 \%$ atau 0,05 yang berarti memiliki data yang terdistribusi normal. Sehingga data yang digunakan pada persamaan struktur I maupun struktur II dalam penelitian ini layak digunakan.

2. Uji Multikolinearitas

Uji Multikolinearitas digunakan untuk mengidentifikasi apakah memiliki keterkaitan hubungan atau korelasi antara variabel-variabel independen atau tidak. Jika didalam hasil pengujian terdapat variabel independen yang saling terikat, maka model regresi yang digunakan tidak layak karena akan membuat bias. Masalah multikolinearitas dapat di identifikasi dengan melihat dari besarnya nilai correlation antar variabel. Jika nilai correlation melebihi angka 0,90 maka mengindikasikan model regresi yang digunakan terdapat multikolinearitas. Berikut merupakan hasil dari uji multikolinearitas pada penelitian ini.

Tabel 4.3

Uji Multikolinearitas Persamaan Struktur I LNX1 LNX2

\begin{tabular}{lcc} 
& LNX1 & \multicolumn{1}{c}{ LNX2 } \\
\hline \hline LNX1 & 1.000000 & 0.172147 \\
LNX2 & 0.172147 & 1.000000 \\
Sumber & Data Sekunder, & diolah
\end{tabular}

Tabel 4.4

Uji Multikolinearitas Persamaan Struktur II

\begin{tabular}{crrr} 
& LNX1 & \multicolumn{1}{c}{ LNX2 } & \multicolumn{1}{c}{ LNX3 } \\
\hline \hline LNX1 & 1.000000 & 0.172147 & -0.178239 \\
LNX2 & 0.172147 & 1.000000 & -0.766136 \\
LNX3 & -0.178239 & -0.766136 & 1.000000
\end{tabular}

Sumber : Data Sekunder, diolah

Berdasarkan hasil uji multikolinearitas diatas, baik persamaan struktur I maupun struktur II tidak ditemukan masalah multikolinearitas pada masing-masing model regresi yang digunakan dalam penelitian ini, karena nilai correlation dari masing-masing persamaan struktur memiliki nilai correlation yang lebih kecil dari 0,90 .

3. Uji Heteroskedastisitas

Uji Heteroskedastisitas digunakan untuk mengetahui apakah didalam model regresi yang digunakan terjadi ketidaksamaan varians dari residual satu pengamatan ke pengamatan lain. Apabila varians dari residual satu pengamatan kepengamatan lain sama atau tetap, maka disebut homoskedastisitas dan jika berbeda maka disebut heteroskedastisitas. Penelitian ini menggunakan uji Harvey-Godfret dalam melakukan pengujian heteroskedastisitas dengan menggunakan logaritma natural dari kuadrat 
residual. Uji Harvey-Godfrey yang membandingkan hasil nilai p-value / Prob. Chi Square dengan $\alpha=5 \%$ atau 0,05 . Berikut hasil dari uji heteroskedastisitas:

Tabel 4.5

Uji Heteroskedastisitas Persamaan Struktur I

Heteroskedasticity Test: Harvey

\begin{tabular}{llll}
\hline \hline F-statistic & 0.116119 & Prob. F(2,137) & 0.8905 \\
Obs*R-squared & 0.236922 & Prob. Chi-Square(2) & 0.8883 \\
Scaled explained SS & 0.416228 & Prob. Chi-Square(2) & 0.8121 \\
\hline
\end{tabular}

Sumber : Data Sekunder, diolah

Tabel 4.6

Uji Heteroskedastisitas Persamaan Struktur II

Heteroskedasticity Test: Harvey

\begin{tabular}{llll}
\hline \hline F-statistic & 0.396336 & Prob. F(3,136) & 0.7558 \\
Obs*R-squared & 1.213369 & Prob. Chi-Square(3) & 0.7498 \\
Scaled explained SS & 0.938028 & Prob. Chi-Square(3) & 0.8162 \\
\hline \hline
\end{tabular}

Sumber : Data Sekunder, diolah

Berdasarkan hasil uji heteroskedastisitas diatas menunjukkan bahwa nilai Prob. Chi Square lebih besar dari a $=5 \%$ atau 0,05. Maka data dalam persamaan struktur I maupun struktur II dalam penelitian ini tidak terindikasi adanya masalah heteroskedastisitas.

4. Uji Autokorelasi

Uji Autokorelasi digunakan untuk mengetahui apakah dalam suatu model terdapat korelasi antara residual satu observasi dengan residual observasi lainnya, jika terdapat korelasi maka model yang digunakan terdapat autokorelasi. Berikut uji autokorelasi pada persamaan struktur I dan persamaan struktur II.

\section{Tabel 4.7}

Uji Autokorelasi Persamaan Struktur I

\begin{tabular}{c|c|c|c|c}
\hline $\begin{array}{c}\text { Autokorelasi } \\
\text { Positif }\end{array}$ & $\begin{array}{c}\text { Tidak dapat } \\
\text { disimpulkan }\end{array}$ & $\begin{array}{c}\text { Tidak Terdapat } \\
\text { Autokorelasi }\end{array}$ & $\begin{array}{c}\text { Tidak dapat } \\
\text { disimpulkan }\end{array}$ & $\begin{array}{c}\text { Autokorelasi } \\
\text { Negatif }\end{array}$ \\
\hline 1,6950 & 1,7529 & 2,161084 & 2,2471 & 2,305 \\
\hline $\mathrm{dL}$ & $\mathrm{dU}$ & Nilai DW stat. & $4-\mathrm{dU}$ & $4-\mathrm{dL}$ \\
\hline
\end{tabular}

Sumber : Data Sekunder, diolah

Tabel 4.8

Uji Autokorelasi Persamaan Struktur II

\begin{tabular}{c|c|c|c|c}
\hline $\begin{array}{c}\text { Autokorelasi } \\
\text { Positif }\end{array}$ & $\begin{array}{c}\text { Tidak dapat } \\
\text { disimpulkan }\end{array}$ & $\begin{array}{c}\text { Tidak Terdapat } \\
\text { Autokorelasi }\end{array}$ & $\begin{array}{c}\text { Tidak dapat } \\
\text { disimpulkan }\end{array}$ & $\begin{array}{c}\text { Autokorelasi } \\
\text { Negatif }\end{array}$ \\
\hline 1,6804 & 1,7678 & 1,797821 & 2,2322 & 2,3196 \\
\hline $\mathrm{dL}$ & $\mathrm{dU}$ & Nilai DW stat. & $4-\mathrm{dU}$ & $4-\mathrm{dL}$ \\
\hline
\end{tabular}

Sumber : Data Sekunder, diolah

Berdasarkan uji autokorelasi diatas menunjukkan bahwa model regresi yang digunakan dalam persamaan struktur I maupun persamaan struktur II tidak terdapat masalah autokorelasi, sehingga data dari residual satu observasi dengan residual observasi lainnya tidak terdapat korelasi. 


\subsection{Uji Hipotesis}

Uji hipotesis digunakan untuk mengetahui apakah koefisien regresi yang dihasilkan dalam penelitian ini signifikan atau tidak. Pengujian hipotesis terdapat tiga uji dilakukan dalam penelitian ini yaitu, uji koefisien determinasi, uji $F$ (uji simultan), uji $t$ (uji parsial), dan analisis jalur (path analysis).

1. Uji Koefisien Determinasi $\left(\mathrm{R}^{2}\right)$

Uji Koefisien Determinasi $\left(\mathrm{R}^{2}\right)$ dilakukan untuk mengetahui seberapa besar variabel independen dalam menjelaskan variabel dependen yang digunakan dalam penelitian ini. Berikut hasil uji koefisien determinasi $\left(\mathrm{R}^{2}\right)$ pada persamaan struktur I dan struktur II.

Tabel 4.9

Uji Koefisien Determinasi $\left(\mathbf{R}^{2}\right)$ Persamaan Struktur I

$\begin{array}{ll}R \text { Squared } & 0,450932 \\ \text { Adjusted R - Squared } & 0,442916\end{array}$

Sumber : Data Sekunder, diolah

Tabel 4.10

Uji Koefisien Determinasi $\left(\mathbf{R}^{2}\right)$ Persamaan Struktur II

\begin{tabular}{lc}
$R$ Squared & 0,883773 \\
Adjusted $R-$ Squared & 0,851784 \\
\hline Sumber : Data Sekunder, diolah &
\end{tabular}

2. Uji F (Uji Simultan)

Uji F digunakan untuk mengetahui apakah seluruh variabel bebas berpengaruh secara simultan terhadap variabel terikat. Untuk mengetahui pengaruh secara simultan dari seluruh variabel bebas terhadap variabel terikat secara signifikan atau tidak signifikan dengan membandingkan probabilitas F-statistik dengan taraf signifikansi $\alpha=5 \%$ atau 0,05. Jika probabilitas F-statistik lebih rendah dari $\alpha=5 \%$ atau 0,05 maka $\mathrm{H}_{0}$ ditolak dan $\mathrm{H}_{1}$ diterima, artinya seluruh variabel bebas yang digunakan berpengaruh secara simultan dan signifikan terhadap variabel terikat. Berikut nilai F-statistik pada persamaan model I yang menggunakan random effect model dan persamaan model II yang menggunakan fixed effect model dalam estimasi model regresi.

Tabel 4.11

Uji F (Uji Simultan) Persamaan Struktur I

$\begin{array}{lc}\text { F-statistic } & 56,25676 \\ \text { Prob. (F-statistic) } & 0,00000\end{array}$

Sumber : Data Sekunder, diolah

Tabel 4.12

Uji F (Uji Simultan) Persamaan Struktur II

\begin{tabular}{ll}
\hline F-statistic & 27,62735 \\
Prob. (F-statistic) & 0,000000
\end{tabular}

Sumber : Data Sekunder, diolah

3. Uji t-Statistik (Uji Parsial)

Uji t-Statistik dilakukan untuk mengetahui apakah variabel independen berpengaruh secara parsial terhadap variabel dependen untuk melihat pengaruh secara parsial dengan membandingkan nilai probabilitas dengan taraf signifikansi $\alpha=5 \%$ atau 0,05 . Jika nilai probabilitas lebih rendah dari $\alpha=5 \%$ atau 0,05 maka $\mathrm{H}_{0}$ ditolak dan $\mathrm{H}_{1}$ diterima, artinya variabel independen yang diuji secara parsial berpengaruh dan signifikan terhadap variabel dependen. Berikut nilai probabilitas pada persamaan model 
I yang menggunakan random effect model dan persamaan model II yang menggunakan fixed effect model dalam estimasi model data panel.

Tabel 4.13

Uji Estimasi Data Panel Persamaan Struktur I

\begin{tabular}{ccccc}
\hline Variabel & Coefficient & Std. Error & $t$-Statistic & Prob. \\
\hline C & 0,191513 & 0,151269 & 1,266043 & 0,2076 \\
LnX1 & 0,025466 & 0,035997 & 0,707450 & 0,4805 \\
LnX2 & $-0,840643$ & 0,078972 & $-10,64482$ & 0,000 \\
\hline
\end{tabular}

Sumber : Data Sekunder, diolah

Tabel 4.14

Uji Estimasi Data Panel Persamaan Struktur II

\begin{tabular}{ccccc}
\hline Variabel & Coefficient & Std. Error & $t$-Statistic & Prob. \\
\hline C & 1,568903 & 0,180501 & 8,691923 & 0,0000 \\
LnX1 & 0,301927 & 0,054201 & 5,570501 & 0,0000 \\
LnX2 & 0,009955 & 0,164850 & 0,060385 & 0,9520 \\
LnX3 & 0,318889 & 0,135252 & 2,357749 & 0,0202 \\
\hline
\end{tabular}

Sumber : Data Sekunder, diolah

4. Analisis Jalur (Path Analysis)

Untuk mengetahui apakah pengaruh tidak langsung signifikan atau tidak, maka dilakukan uji sobel untuk mengetahui signifikansi nilai coefficient hubungan tersebut. Apabila $p$-value sobel test lebih kecil dari nilai signifikansi $a=5 \%$ atau 0,05 , maka hipotesis diterima, sehingga variabel intervening memiliki pengaruh. Berikut hasil perhitungan koefisien dari uji sobel (Sobel Test) pengaruh tidak langsung :

Tabel 4.15

Hasil Analisis Jalur Pengaruh Tidak Langsung I

\begin{tabular}{ccccc}
\hline Indirect Effect & Coefficient & t-Statistic & Std. Error & $\begin{array}{c}p \text {-value } \\
\text { sobel test }\end{array}$ \\
\hline $\mathrm{X} 1-\mathrm{Z}-\mathrm{Y}$ & 0,0081208273 & 0,67760218 & 0,01198465 & 0,49802396 \\
\hline
\end{tabular}

Sumber : Data Sekunder, diolah

Berdasarkan tabel diatas dapat dijelaskan bahwa pengaruh secara tidak langsung memiliki nilai $p$-value sobel test yang didapatkan sebesar 0,49802396 maka nilai p-value sobel test lebih besar dari tingkat signifikansi $a=0,05$. Dapat disimpulkan $\mathrm{H}_{0}$ diterima, sehingga tidak adanya pengaruh mediasi.

Tabel 4.16

Hasil Analisis Jalur Pengaruh Tidak Langsung II

\begin{tabular}{ccccc}
\hline Indirect Effect & Coefficient & t-Statistic & Std. Error & $\begin{array}{c}p \text {-value } \\
\text { sobel test }\end{array}$ \\
\hline $\mathrm{X} 2-\mathrm{Z}-\mathrm{Y}$ & $-0,268071806$ & $-2,30195049$ & 0,1164542 & 0,02133796 \\
\hline
\end{tabular}

Sumber : Data Sekunder, diolah

Berdasarkan tabel diatas dapat dijelaskan bahwa pengaruh secara tidak langsung memiliki nilai $p$-value sobel test yang didapatkan sebesar 0,02133796 maka nilai $p$-value sobel test lebih besar dari tingkat signifikansi $a=0,05$. Dapat disimpulkan $\mathrm{H}_{0}$ ditolak, sehingga adanya pengaruh mediasi.

\subsection{Pembahasan}

\subsubsection{Profitabilitas berpengaruh terhadap Nilai Perusahaan}

Hasil pengujian hipotesis 1 menunjukkan bahwa profitabilitas (ROA) berpengaruh positif dan signifikan terhadap nilai perusahaan (PBV). Hasil pengujian hipotesis ini 
memiliki arah positif dengan tingkat signifikansi 0,0000 lebih kecil dari taraf signifikansi $(0,000<0,05)$. Artinya hipotesis pertama $\left(\mathrm{H}_{1}\right)$ diterima yaitu profitabilitas berpengaruh positif dan signifikan terhadap nilai perusahaan. Hasil penelitian ini juga sejalan dengan penelitian yang dilakukan oleh Sari \& Sedana, (2020); Putra \& Sedana, (2019); Mulyani et al., (2017); Nurminda et al., (2017); Sabrin, Sarita, Takdir, \& Sujono, (2016) dan Wulandari, (2013) menyatakan bahwa profitabilitas berpengaruh terhadap nilai perusahaan.

\subsubsection{Likuiditas berpengaruh terhadap Nilai Perusahaan}

Hasil pengujian hipotesis 2 menunjukkan bahwa likuiditas (CR) tidak berpengaruh terhadap nilai perusahaan (PBV). Hasil pengujian hipotesis ini memiliki nilai signifikansi sebesar 0,9520 lebih besar dari taraf signifikansi $(0,9520>0,05)$. Artinya hipotesis kedua $\left(\mathrm{H}_{2}\right)$ ditolak yaitu likuiditas tidak berpengaruh signifikan terhadap nilai perusahaan. Hasil penelitian ini sejalan dengan penelitian yang dilakukan oleh Aslindar \& Lestari, (2020); Rahmatullah, (2019) dan Wulandari, (2013) yang menyatakan likuiditas tidak memiliki pengaruh terhadap nilai perusahaan.

\subsubsection{Profitabilitas berpengaruh terhadap Struktur Modal}

Hasil pengujian hipotesis 3 menunjukkan bahwa profitabilitas (ROA) tidak berpengaruh terhadap nilai perusahaan (PBV). Hasil pengujian hipotesis ini memiliki nilai signifikansi sebesar 0,4805 lebih besar dari taraf signifikansi $(0,4805>0,05)$. Artinya hipotesis ketiga $\left(\mathrm{H}_{3}\right)$ ditolak yaitu profitabilitas tidak berpengaruh signifikan terhadap struktur modal. Hasil penelitian ini sejalan dengan penelitian yang dilakukan oleh Aslindar \& Lestari, (2020) yang menyatakan profitabilitas tidak memiliki pengaruh terhadap struktur modal.

\subsubsection{Likuiditas berpengaruh terhadap Struktur Modal}

Hasil pengujian hipotesis 4 menunjukkan bahwa likuiditas (CR) berpengaruh terhadap nilai perusahaan (PBV). Hasil pengujian hipotesis ini memiliki nilai signifikansi sebesar 0,0000 lebih kecil dari taraf signifikansi $(0,0000<0,05)$. Artinya hipotesis keempat $\left(\mathrm{H}_{4}\right)$ diterima yaitu likuiditas berpengaruh negatif dan signifikan terhadap struktur modal. Hasil penelitian ini sesuai dengan penelitian yang dilakukan oleh Sari \& Sedana, (2020); Aslindar \& Lestari, (2020); Putra \& Sedana, (2019); dan Mulyani et al., (2017) menyatakan bahwa likuiditas memiliki pengaruh terhadap struktur modal.

\subsubsection{Struktur Modal berpengaruh terhadap Nilai Perusahaan}

Hasil pengujian hipotesis 5 menunjukkan bahwa struktur modal (DER) berpengaruh terhadap nilai perusahaan (PBV). Hasil pengujian hipotesis ini memiliki nilai signifikansi sebesar 0,0202 lebih kecil dari taraf signifikansi $(0,0202<0,05)$. Artinya hipotesis keempat $\left(\mathrm{H}_{5}\right)$ diterima yaitu struktur modal berpengaruh positif dan signifikan terhadap nilai perusahaan. Hasil penelitian ini sesuai dengan penelitian yang dilakukan oleh Savitri et al., (2021); Sari \& Sedana, (2020); Aslindar \& Lestari, (2020); Putra \& Sedana, (2019); dan Mulyani et al., (2017) menyatakan bahwa struktur modal memiliki pengaruh terhadap nilai perusahaan.

\subsubsection{Profitabilitas terhadap Nilai Perusahaan Melalui Struktur Modal}

Berdasarkan hasil penelitian ini yang menggunakan variabel intervening atau mediasi yaitu struktur modal yang mengidentifikasi profitabilitas memiliki pengaruh terhadap nilai perusahaan melalui struktur modal. Hal tersebut dapat dilihat dari $p$-value sobel test yang didapatkan sebesar 0,49802396 maka nilai tersebut lebih besar dari tingkat signifikansi $a=0,05$ dan memiliki nilai koefisien sebesar 0,081208273 . Sehingga dapat disimpulkan bahwa profitabilitas terhadap nilai perusahaan melalui struktur modal tidak memiliki pengaruh yang signifikan. Hasil penelitian ini sejalan dengan penelitian yang dilakukan oleh Wulandari, (2013); Rahmatullah, (2019); Aslindar \& Lestari, (2020); dan 
Savitri et al., (2021) menyatakan struktur modal belum mampu memediasi pengaruh profitabilitas terhadap nilai perusahaan.

\subsubsection{Likuiditas terhadap Nilai Perusahaan Melalui Struktur Modal}

Berdasarkan hasil penelitian ini yang menggunakan variabel intervening atau mediasi yaitu struktur modal yang mengidentifikasi likuiditas memiliki pengaruh terhadap nilai perusahaan melalui struktur modal. Hal tersebut dapat dilihat dari p-value sobel test yang didapatkan sebesar 0,02133796 maka nilai tersebut lebih kecil dari tingkat signifikansi $a=0,05$ dan memiliki nilai koefisien sebesar -0,268071806. Sehingga dapat disimpulkan bahwa likuiditas terhadap nilai perusahaan melalui struktur modal memiliki pengaruh yang signifikan. Hasil penelitian ini sejalan dengan penelitian yang telah dilakukan oleh Cheung et al., (2015); Vo \& Hong (2016); Shammakhi \&Azita (2016); dan Arggawal \& Purna (2017) yang menunjukan bahwa likuiditas berpengaruh terhadap nilai perusahaan melalui struktur modal.

\section{KESIMPULAN DAN SARAN}

\subsection{Kesimpulan}

Berdasarkan hasil penelitian data dan uji statistik yang telah dilakukan, maka dapat diperoleh kesimpulan :

1. Profitabilitas (ROA) berpengaruh positif dan signifikan terhadap nilai perusahaan (PBV). Hal ini menunjukkan bahwa semakin tinggi rasio profitabilitas pada perusahaan akan cenderung meningkatkan nilai perusahaan. Ini mencerminkan bahwa perusahaan yang mengalami peningkatan laba memiliki kinerja yang baik, sehingga nilai perusahaan akan meningkat melalui harga saham perusahaan.

2. Likuiditas (CR) tidak berpengaruh terhadap nilai perusahaan (PBV). Hal ini menunjukkan bahwa semakin tinggi ataupun rendah rasio likuiditas pada perusahaan cenderung tidak akan meningkatkan atau menurunkan nilai perusahaan. Hal ini dikarenakan investor hanya melihat pada kegiatan usaha perusahaan tanpa melihat likuiditas perusahaan.

3. Profitabilitas (ROA) tidak berpengaruh terhadap struktur modal (DER). Hal ini menunjukkan bahwa rasio profitabilitas yang tinggi tidak akan meningkatkan struktur modal. Profitabilitas yang meningkat mengindikasikan perusahaan semakin efisien dalam menggunakan seluruh modal yang dimiliki sehingga perusahaan tidak harus meminjam dana dari pihak luar.

4. Likuiditas (CR) berpengaruh negatif dan signifikan terhadap struktur modal (DER). Hal ini tercermin dengan ukuran rasio lancar yang semakin besar menunjukkan bahwa perusahaan telah berhasil melunasi utang jangka pendeknya. Berkurangnya utang jangka pendek berakibat menurunnya proporsi utang dalam stuktur modal.

5. Struktur modal (DER) berpengaruh terhadap nilai perusahaan (PBV). Hal ini berarti bahwa peningkatan struktur modal berpotensi meningkatkan nilai perusahaan daripada risiko. Hal ini dikarenakan dengan struktur modal yang baik akan meningkatkan kepercayaan investor untuk melakukan investasi dengan menanamkan dananya pada perusahaan.

6. Profitabilitas (ROA) secara tidak langsung tidak berpengaruh terhadap nilai perusahaan (PBV) dengan struktur modal (DER) sebagai variabel intervening. Hal ini dikarenakan perusahaan yang memiliki tingkat profitabilitas yang tinggi maupun struktur modal akan secara independen memberikan signal positif terhadap nilai perusahaan.

7. Likuiditas (CR) secara tidak langsung berpengaruh terhadap nilai perusahaan (PBV) dengan struktur modal (DER) sebagai variabel intervening. Hal ini tercermin ketika 
perusahaan dengan tingkat likuiditas yang tinggi akan memiliki tingkat kewajiban jangka pendek yang rendah karena perusahaan dapat memenuhi dan melunasi seluruh kewajiban jangka pendek tepat waktu., sehingga dapat menarik minat investor untuk membeli saham tersebut sekaligus mencerminkan nilai perusahaan yang tinggi.

\subsection{Saran}

Saran untuk penelitian selanjutnya yaitu sebagai berikut:

1. Profitabilitas dapat digunakan sebagai barometer keberhasilan perusahaan dalam memperoleh laba sehingga dapat meningkatkan nilai perusahaan.

2. Likuditas perusahaan perlu diperhatikan agar dapat mengetahui kemampuan perusahaan dalam memenuhi kewajiban jangka pendeknya.

3. Profitabilitas yang tinggi pada perusahaan dapat meminimalisir perusahaan untuk mencari struktur modal diluar perusahaan.

4. Sumber dana internal yang diperoleh dapat digunakan untuk mebiayai proporsi utang jangka pendek dalam struktur modal perusahaan.

5. Perusahaan perlu mengatur struktur modal yang dimiliki untuk dapat digunakan secara efisien yang dapat meningkatkan nilai perusahaan.

6. Menggunakan profitabilitas yang dimiliki sebaik mungkin tanpa harus menggunakan hutang jangka pendek agar meningkatkan nilai perusahaan.

7. Sebaiknya perusahaan yang memiliki likuiditas yang tinggi dapat menyeimbangkan dengan kemampuannya dalam membayar utang.

\section{DAFTAR PUSTAKA}

Aslindar, D. A., \& Lestari, U. P. (2020). Pengaruh Profitabilitas, Likuiditas Dan Peluang Pertumbuhan Terhadap Nilai Perusahaan Dengan Struktur Modal Sebagai Variabel Intervening. Dinamika Akuntansi, Keuangan Dan Perbankan, 9, 91-106.

Azmi, N., Isnurhadi, I., \& Hamdan, U. (2018). Pengaruh Profitabilitas, Ukuran Perusahaan Terhadap Nilai Perusahaan Dengan Struktur Modal Sebagai Variabel Intervening Pada Perusahaan Manufaktur Yang Terdaftar Di BEI. JEMBATAN - Jurnal Ilmiah Manajemen Bisnis Dan Terapan. https://doi.org/10.29259/jmbt.v15i2.6657

Besley, S., \& Brigham, E. F. (2008). Essentials of Managerial Finance. In Thomson SouthWestern.

Brealey, R. A., Myers, S. C., \& Allen, F. (2011). Principles of Corporate Finance - Principles of Corporate Finance (10th Edition).pdf.

Brigham, E. F., \& Houston, J. F. (2014). Dasar-Dasar Manajemen Keuangan Edisi 11 Buku 1. In Salemba Empat Jakarta.

Copeland, T., Weston, F., \& Shastri, K. (2005). Financial Thoery and Corporate Policy 4e. In PEARSON.

Ghozali, I. (2013). Ghozali, Imam (2013). Aplikasi Analisis Multivariate Dengan Program IBM SPSS 21Update PLS Regresi. Semarang: Badan Penerbit Universitas Diponegoro.

Husnan, S. (2015). Dasar-dasar Teori Portofolio \& Analisis Sekuritas Edisi Kelima. In Yogyakarta (ID): Penerbit dan Percetakan UPP STIM YKPN.

Mahendra, A., Sri artini, L. gede, \& Suarjaya, A. G. (2012). Pengaruh Kinerja Keuangan Terhadap Nilai Perusahaan Manufaktur di Bursa Efek Indonesia. Jurnal Manajemen, Stategi Bisnis, Dan Kewirausahaan.

Manoppo, H., \& Arie, F. (2016). Pengaruh Struktur Modal, Ukuran Perusahaan Dan Profitabilitas Terhadap Nilai Perusahaan Otomotif Yang Terdaftar Di Bursa Efek Indonesia Periode 2011-2014. Jurnal Riset Ekonomi, Manajemen, Bisnis Dan 
Akuntansi. https://doi.org/10.35794/emba.v4i2.13082

Miglo, A. (2016). Capital Structure in the Modern World. In Capital Structure in the Modern World. https:/ / doi.org/10.1007/978-3-319-30713-8

Mulyani, S., Amboningtyas, D., \& Fathoni, A. (2017). The Influence Of Liquidity, Profitability, Leverage On Firm Value With Capital Structure As Intervening Variable. Journal of Manajemen, Unpand.

Nurminda, A., Isynuwardhana, D., \& Nurbaiti, A. (2017). The Influence Of Profitability, Leverage, And Firm Size Toward Firm Value. E-Proceeding of Management.

Putra, I. G. W. R., \& Sedana, I. B. P. (2019). Capital Structure As A Mediation Variable: Profitability And Liquidity On Company Value In Real Estate Companies In Indonesia Stock Exchange. International Research Journal of Management, IT and Social Sciences. https:// doi.org/10.21744/irjmis.v6n4.640

Rahmatullah, D. D. (2019). Pengaruh Profitabilitas Dan Likuiditas Terhadap Nilai Perusahaan Dengan Struktur Modal Sebagai Variabel Intervening. Jurnal Akuntansi AKUNESA.

Sabrin, Sarita, B., Takdir, D. S., \& Sujono. (2016). The Effect of Profitability on Firm Value in Manufacturing Company at Indonesia Stock Exchange. The International Journal of Engineering And Science (IJES), 5(10), PP 81-89.

Sari, I. A. G. D. M., \& Sedana, I. B. P. (2020). Profitability And Liquidity On Firm Value And Capital Structure As Intervening Variable. International Research Journal of Management, IT and Social Sciences. https://doi.org/10.21744/irjmis.v7n1.828

Savitri, D. A. M., Kurniasari, D., \& Mbiliyora, A. (2021). Pengaruh Profitabilitas dan Ukuran Perusahaan terhadap Nilai Perusahaan dengan Struktur Modal sebagai Variabel Intervening (Studi pada Perusahaan Manufaktur yang terdaftar di Bursa Efek Indonesia tahun 2017-2019). Jurnal Akuntansi Dan Pajak. https://doi.org/http://dx.doi.org/10.29040/jap.v21i2.1825

Sekaran, U. (2011). Metodologi Penelitian untuk Bisnis. Jakarta: Salemba Empat. Annals of Tourism Research.

Sekaran, U., \& Bougie, R. (2016). Reserach Methods for Bussiness A Skill-Bulding Approach. Printer Trento Srl.

Septriana, I., \& Mahaeswari, H. F. (2019). Pengaruh Likuiditas , Firm Size , dan Profitabilitas Terhadap Nilai Perusahaan. Jurnal Akuntansi Indonesia.

Sugiyono. (2013). Metode Penelitian Pendidikan Pendekatan Kuantitaif, Kualitatif, dan R\&D. https://doi.org/10.1. In Metode Penelitian Pendidikan Pendekatan Kuantitaif, Kualitatif, dan RED.

Van Horne, J. C., Wachowicz, J. R., \& John, M. (2005). Prinsip-prinsip Manajemen Keuangan, diterjemahkan oleh Dewi Fitriasari dan Deny Arnos Kwary. Jakarta: Salemba Empat.

Wulandari, D. R. (2013). Pengaruh Profitabilitas, Operating Leverage, Likuiditas Terhadap Nilai Perusahaan Dengan Struktur Modal Sebagai Intervening. Accounting Analysis

www.kontan.co.id Journal. https://doi.org/10.15294/aaj.v2i4.4172

www.ojk.go.id

www.idx.co.id 